\title{
Dubbing Method and Learning Videos for Improving Students' English Speaking
}

\section{Dian Christina1*, Dwi Megista Putri², Laila Marhayati 3}

1,2,3 Universitas Putra Indonesia "YPTK" Padang, Padang, Indonesia

\section{ART ICLE INFO}

Article history:

Received August 23, 2021

Revised August 24, 2021

Accepted September 14, 2021

Available online October 25, 2021

Kata Kunci:

Metode Dubbing, Kosakata,

Pengucapan

Keywords:

Dubbing Method, Vocabulary,

Pronunciation

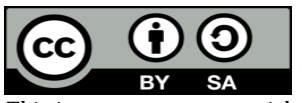

This is an open access article under the $\mathrm{CC}$ BY-SA license.

Copyright (C) 2021 by Author. Published by Universitas Pendidikan Ganesha.

\begin{abstract}
A B S T R A K
Sebagian besar mahasiswa masih memandang bahasa Inggris sangat sulit untuk dipelajari. Selain itu mahasiswa tidak percaya diri dan takut melakukan kesalahan. Tujuan dari penelitian ini adalah menganalisis kemampuan siswa berbicara bahasa Inggris setelah menggunakan metode dubbing dan media video pembelajaran. Model penelitian eksperimen yang digunakan adalah one group of pre-test and post-test eksperimental design. Metode pengumpulan data eksperimen terdiri dari observasi, wawancara, dan perekaman. Analisis data melalui pengelompokan dan perbandingan berdasarkan kategori; kategori tidak puas (AS), kategori cukup $(F)$, kategori baik $(G)$, kategori sangat baik (V), dan kategori sangat baik (E). Hasil penelitian berdasarkan pre-test masuk dalam kategori US = 7 siswa, $F=21$ siswa, $G=13$ siswa, $V G=3$ siswa dan $E=0$, tidak ditemukan hasil dan post test hasil belajar siswa US $=0$, tidak ditemukan hasil, $F=6$ siswa, $G=20$ siswa, $V G=$ 17 siswa dan $E=1$ siswa. Kemudian efek positif dari penggunaan metode dubbing hasil adalah kemampuan siswa dalam berbicara bahasa Inggris meningkat lebih tinggi, mengacu pada hasil pre-test kategori kemampuan siswa ditemukan dalam kategori US dan tidak ditemukan kategori yang sama pada hasil post-test, siswa ' kategori kemampuan tidak ada hasil yang ditemukan dalam kategori $E$ dan kategori AS. Jadi metode dubbing bekerja secara efektif dalam proses pengajaran untuk meningkatkan kemampuan berbicara bahasa Inggris siswa.
\end{abstract}

\section{A B S T R A C T}

Most students still view English as very difficult to learn. In addition, students are not confident and afraid to make mistakes. This study aimed to analyze the students' ability to speak English after using the dubbing method and learning video media. The experimental research model used is one group of pre-post-test experimental design. Data group design methods consist of observation, interviews, and recording. Data analysis through grouping and comparison by category; dissatisfied category (AS), moderate category (F), good category (G), very good category (V), and very good category (E). The results of the research based on the pre-test were categorized as US $=7$ students, $F=$ 21 students, $G=13$ students, $V G=3$ students and $E=0$, found no results and post-test results for US students $=0$, found no results, $\mathrm{F}=6$ students, $\mathrm{G}=20$ students, $\mathrm{VG}=17$ students and $\mathrm{E}=1$ student. Then the positive effect of using the result dubbing method is that the student's ability in speaking English is higher, referring to the results of the pretest category of students' ability found in the US category and not found in the same category in the post-test results, students' ability category does not exist. Results were found in category E and category AS. So the dubbing method works effectively in the teaching process to improve students' English speaking skills.

\section{INTRODUCTION}

The demand for the ability to communicate in English has always been a mandatory requirement for everyone who wants to get a better job (Hill et al., 2020; Sert \& Boynueğri, 2017; Sirivedin et al., 2018). It is a matter of controversy every year. Competition with graduates with higher education and experience, the suitability of the vocational field with the availability of current job opportunities, and limited access to employment are some of the challenges faced by undergraduate graduates to compete in finding work (Chamundeswari, 2013; Davidescu et al., 2020; Shaukat et al., 2019). In general, most students still view English as a theoretical book and have not been applied or practised as a habit in daily activities at universities and society (Alkubaidi, 2018; Ja'ashan, 2020; Khusniyah \& Hakim, 2019). Of course, this is not entirely a student's weakness, but the conditions around them also have the same limitations. Students understand better if they communicate using the local language or only Indonesian (Friantary \& Martina, 2018; Ratminingsih, 2018; Surjono, 2016). Meanwhile, teaching English at the University is still impossible to be done entirely in English (Lestar, 2021). With various English skills, students tend to be weak in speaking English (Djami \& Kuswandono, 2020; Khotimah et al., 2019). 
Teaching English interspersed with Indonesian is something that English teachers usually do to understand students.

Based on the observations made, it was obtained that most of the students chose not to communicate in English. It is because they are not confident and afraid to make mistakes. Students' low level of confidence in speaking English must be assisted with guidance and direction so that they are willing to try and learn from mistakes. In terms of the time allocation set by the curriculum, it is felt to be very lacking (Friantary \& Martina, 2018; Noge, 2019; Ratminingsih, 2018; Suhandra, 2018). With only two hours of meetings in one week, it is tough for lecturers to achieve learning targets. The limited time to study English at the University is a difficult challenge to produce graduates with good English language skills. A very diverse approach to teaching English is expected to accommodate students' needs for English. In this case, teacher creativity is a demand and a real challenge that must be recognized (Hawkins, 2018; Kamelia, 2019; Liang et al., 2011; Megawati \& Utami, 2020). The most important thing to do is to strengthen the foundation and activeness of students in speaking English orally and in writing and gradually develop them towards specific skills (Ammade et al., 2020; Wichadee, 2011). Pronunciation difficulties for most students result from differences in the sound of their first language with the sound of their second language. It means that pronunciation can be a student's internal and external factors. Internal factors because each student has a different sound organ. Therefore, to produce speech, some utterances produce different sound characteristics. External factors because students have different mother tongues. Mother's tongue impacts the target language (Risnawati \& Nuraeni, 2019; Szanto, 2020). Fluency in everyday life often refers to oral proficiency in a particular language, both native and foreign ((Khong et al., 2017; Lyashenko \& Malinina, 2015; Zabrodina et al., 2015). If accuracy knows what to say if the pronunciation is the resulting speech and fluency knows how to say it.

So, the keyword is that speaking ability or skill is right on accuracy in language pronunciation. In this case, how can students speak English fluently and with proper pronunciation (Arfani \& Sulistia, 2019; Liyana \& Kurniawan, 2019; Zuhriyah, 2017). One of the challenges for educators in the current era of disruption is creating students with good English speaking skills (Iftakhar, 2013; Yusuf \& Mabagits, 2020). In fact, during the COVID-19 pandemic, educators are thinking hard about using existing technology to support the learning process (Aini et al., 2020; Sahin \& Yilmaz, 2020). Many students face some difficulties when they want to communicate in English even though they have been studying English for years. In a series of teaching and learning processes, of course, there is reciprocity from students to educators (Asmi et al., 2018; Hatlevik et al., 2018; Misla \& Mawardi, 2020). After participating in the teaching and learning process, expressions of feelings, messages, and impressions will be conveyed. The lack of student involvement and participation in the teaching and learning process is an obstacle for these students to excel (Noge, 2019; Syawaluddin \& Iswari, 2015). Reflection activities like this aim to determine the extent of interest in the success of strategies, approaches and learning techniques applied by educators and identify weaknesses or deficiencies in material presentation and classroom mastery (Dwi et al., 2013; Pratiwi et al., 2018).

One way to increase student interest in learning is to use appropriate learning methods (Afif, 2019; Kusumah et al., 2020; Sartika et al., 2018). In addition, the use of appropriate learning media can also increase students' enthusiasm for learning (Febliza \& Okatariani, 2020; Virgiana \& Wasitohadi, 2016). One strategy that can be done is holding English learning and conversation activities through the dubbing method. When students do dubbing, students are required to fill in the words that match the artist's voice in the silent film. It is in line with the notion of dubbing itself, namely the filling of speech or words (Liu \& Song, 2021; Sánchez-Mompeán, 2021). In cinema, dubbing or what is known as dubbing (dubbing, looping), is the process of recording or replacing character voices. So it can be concluded that dubbing is a voiceover adapted to the conversation in a film in a language that is more readily accepted by the audience who watches it. The most appropriate media used in the dubbing method is learning video. Video is a multimedia material consisting of verbal and non-verbal presentations that display images, narration, and text on the screen simultaneously (Noviyanto et al., 2015; Teng, 2019). Videos can describe settings, actions, emotions, and gestures that provide a significant visual stimulus for language training and learning (Colasante \& Douglas, 2016; Nurrohmah et al., 2018; Sudiarta \& Sadra, 2016). Video screenings in class allow instructors to expose students to authentic cultural information (Putri et al., 2020; Suryansah \& Suwarjo, 2016). It means that videos can be used in teaching English because they can provide great visual stimulation through a combination of illustrations, sounds, graphics, and text. Or dubbing. So that students will be motivated to choose the correct vocabulary to use in filling voices and speaking according to context. The findings of previous studies also state that the dubbing method can be applied to improve student's English skills (Liu \& Song, 2021; Sánchez-Mompeán, 2021). Other research findings also state that learning videos can significantly improve student learning outcomes (Halim, 2017; Mustakim, 2020; Van Alten et al., 2020). It can be concluded that the dubbing method, with learning video media, can help 
students improve their English skills. There is no study on the dubbing method with the help of learning video media in English subjects. This study aimed to analyze the students' ability to speak English before and after the dubbing method experiment. It is hoped that this learning method and media can improve students' mastery of grammar, vocabulary, and pronunciation of English.

\section{RESEARCH METHODS}

This research is a descriptive study that begins with observing student assignments in English, formulating research objectives, collecting data, analyzing data and presenting research results. In the implementation process, it applies a pre-experimental research model. In particular, the pre-experimental method was carried out by giving a test, applying the dubbing method and post-test. Furthermore, from the results of the initial and final tests, a comparison of the effects and changes was made after the dubbing method was applied. In this study, the population was taken from several students studying at Bung Hatta University (UBH). The sample in this study was to take 44 second semester students majoring in English language and literature at Bung Hatta University as informants who were selected sequentially to be observed in order to obtain the data needed in the study. In the data collection stage, including observation, interview and recording techniques to determine students' mastery and speaking skills. The process of implementing the technique is as follows: Researchers conducted observations, interviews and recordings directly to students; Researchers display pictures, objects and ask questions about mastery of English including vocabulary, pronunciation, grammar and fluency and make notes during the observation, interview and recording process; Researchers took documentation (photos and videos) and English notebooks when the experiment was carried out. This study uses an experimental research model namely pre-experimental design: one group pre-test-posttest, reporting very often about the value of new teaching methods or the interest generated by some curriculum innovations. or another reveals that a researcher has measured a group on a dependent variable (01), for example, attitudes toward minority groups, and then introduced a Manipulation experiment (X), perhaps a ten-week curriculum project designed to increase tolerance for ethnic minorities. After the experimental treatment, the researcher again measured the attitude of the group (02) and then took into account the difference between the pretest and post-test scores with reference to the effect of X. Data taken from students between two universities through pre-test and post-test will be analyzed by grouping and explaining mastery of vocabulary, grammar, pronunciation when students speak. The data obtained from the students will be analyzed based on the instrument of 5 categories and the speaking ability assessment range which is described in Table 1.

Table 1. Categories And The Speaking Ability Assessment Range

\begin{tabular}{ll}
\hline Scores & Explanation \\
\hline Excellent & Excellent to use of English. Quite clear oral production. Experiences little or no \\
$(90-100)$ & difficulty in understanding. Almost no errors of phonology, grammar or lexis \\
Very good & Satisfactory verbal communication. Limited number of errors of grammar, lexis or \\
$(80-89)$ & pronunciation. Occasional self-corrections. Little difficulty in understanding. \\
Good & Verbal communication usually fairly satisfactory. Repetition and rephrasing \\
$(70-79)$ & sometimes necessary. Experiences some difficulties in communicating. Some errors \\
Fair & of phonology grammar and lexis \\
$(60-69)$ & Understanding very limited, although communication in everyday topics is \\
Unsatisfactory (59- & possible. Many errors of phonology grammar and lexis \\
fewer) & Extreme difficulty in communication in any subject. Failure to understand \\
& adequately and to make him/herself understand
\end{tabular}

Based on the instruments in the table above, the researchers made five categories with values that were adjusted to the category standards and abilities possessed by students. Categories will be differentiated and analyzed from the unsatisfactory category (US) with a value range of 59-fewer, the fair category (F) with a score range of 60-69, the good category (G) with a score of 70-79, the Very good category (VG) with a score of $80-89$ and excellent category with a score of 90-99. To find the results after categorization, the researcher made one table for each category that was determined from the five categories above with 5 columns in one category table. The first column of the table is students, the second column is category, the third column is the real score obtained by students, the fourth column is the total score of all scores in one category and the fifth column is the average column (average value) of the total score of each category. 


\section{RESULTS AND DISCUSSION}

\section{Result}

The results of research that have been carried out in an effort to improve students' English skills can be seen in the presentation of the results of the pre-test and post-test. From the first category, the unsatisfactory category, there were 7 students who scored below 59 (between scores of 40 to 59). This shows the lowest score of students who have to study again to improve vocabulary mastery, use good and correct grammar and pronunciation according to standards delivered through a video that has been played previously. The second category is the fair category. Of the 44 students who took part in the pretest, there were 21 students who scored above 60 and below 69 . This number is the largest number of the total number of students. Based on the data obtained from the 21 students, there are still many limitations in grammar that show repeated errors. In addition, students have a lack of vocabulary mastery when speaking. From the real data in the class, the pre-test shows the repetition of the same vocabulary and even using Indonesian vocabulary forcibly. Then, there were many incorrect pronunciations when talking about the video. Good category is the third category where 13 people were found who scored 70-79. Based on the data from the pre-test, it was found that there were slight deficiencies in grammar, vocabulary and pronunciation. In repeating the speech in the video, students occasionally show errors in pronunciation but can be understood.

Fourth is very good category. In this category, there were only 3 students out of 44 students who took part in the pre-test. The three students got the same score, namely a score of 80 . They gave the speech results quite smoothly. In the use of grammar can be accepted well. In the use of vocabulary, it shows fluency and mastery and there is no hesitation and few errors when applied in sentences. And in pronunciation, students are quite confident and quite clear every vocabulary mentioned in the sentence according to a recognized standard. In the fifth section is the excellent category. In this category, there is not a single student who achieves a score of 90 . From the data obtained as a whole, it shows that overall students still occupy the highest score with a score of 80 (eighty) and the lowest score is at a score of 57.5. Students are still in the category of unsatisfactory ability, fair, good, very good but not in the excellent category. Because when speaking, students do not show a clear and deep understanding when speaking and do not achieve accuracy in the use of grammar, vocabulary and pronunciation. So it can be concluded that the ability of second semester students majoring in English at Bung Hatta University requires the dubbing method in classroom teaching as an effort to improve clear speaking skills, mastery of grammar, vocabulary and correct pronunciation. In the post-test results, students achieved scores that fall into four categories, namely the fair category, good category, very good category and excellent category. The unsatisfied category (US) was not found but what was found was the fair category (F), good category (G), very good category (VG) and excellent category (E). First, there were no students in the US category. After receiving treatment with the dubbing method, the students' abilities increased as evidenced by the posttest results, which were zero results, while in the pre-test results, several students were found to be in the US category. The second is the fair category (F), it was found that 6 students entered the fair category after receiving treatment with the dubbing method. Of the six students showed a decrease in the number of students compared to the number of students on the pre-test results were more, in other words, the ability of students had increased in the higher categories.

Third, in the good category, there were 20 students who scored in the range of 70-79. The increase in the number included in this category is the highest number from the other categories after students received treatment with the dubbing method, namely the correction of every sentence that arises when students speak English. Fourth, in the post-test results, 17 students were found to be in the very good category with scores in the range of 80-89 after receiving direct method treatment in class. Students' speaking ability has increased and found only 3 people. So the increase in the ability of students after receiving treatment with the dubbing method increased to 17 people from 44 students. Fifth, the ability of students who entered the best category (Excellent) was found in the post-test results of 1 student. The student was proven to improve his English speaking ability after receiving treatment with the dubbing method. The data below describes the results of the pre-test and post-test arranged in tabular form; category, range, pre-test result and post-test result. From the results of both pre-test and post-test above, it shows that there is an increase in student abilities ranging from unsatisfactory abilities to excellent abilities. Changes in ability and can be proven in increasing student scores from low scores to higher grades. This increase is the result of the application of the dubbing method to the second semester students of the Faculty of English Language and Literature at Bung Hatta University.

The improvement of students' speaking ability based on the pre-test and post data above is shown in 5 categories. The first category, namely the unsatisfied category (US), was found to have 7 students who scored below 60 (59-fewer) then after following the dubbing method they received 
corrections for errors when speaking sentences and student expressions. Students showed very good abilities so that in the post-test results, there was not a single student who scored below 60 but all students experienced an increase in ability starting from scores above 60. The increase in the ability of students in the range (value) of 60-69 is evidenced by the results of the pre-test, there are 21 students with an average score of 60.69 then their ability increases after receiving the dubbing method treatment to fewer, namely, 6 students with an average score average, 64.55. So, the ability of students increased by two percent from the previous ability. The increase in student abilities was seen in the good category, starting from the pre-test there were 13 students who scored 70-79, with an average score of 72.11. Furthermore, their average score increased on the post-test results to 72.55. This increase was also accompanied by an increase in the number of students before, 13 people and after the post-test increased to 20 people. Increased student abilities in the very good category (very good category). There were only 3 students in the pre-test with an average score of 80 . While the post-test results showed a very high increase, namely, 17 students with an average score of 81.15. The increase in student abilities in the excellent category (excellent category) can be seen in the table above. In the pre-test, not one student was found to have ability in the very good category but in the post-test results, it was found that 1 student was able to show the best with a score of 90-93 and an average score of 90 .

Improving students' English-speaking skills through the treatment of the dubbing method using different short videos in the pre-test and post-test. This is evidenced by the results of the pre-test which are still relatively low, while the results of the post-test students' speaking skills have improved very well. In the pre-test results, there were 7 students in the unsatisfied category, while in the post-test results, there were no scores below 60 but increased to the fair category. In other words, students' abilities have been shown to increase through the use of the dubbing method in the classroom. The ability of students increased in the fair category. Based on the results of the pre-test, there were 21 students and the results of the final test (post-test) were reduced to 6 students. From this change, it can be concluded that 15 students out of 21 students got an increase in their English speaking skills after following the dubbing method although there were still 6 people who were still in the fair category. The ability of students increased in the good category. From the data in the table shows the results of the pre-test there are 13 students who fall into the category of good ability (good category) and on the results of the post-test, there is an increase in the number of students, namely, 20 students. There are 7 students in the good category. When compared with the results of the pre-test, the results of the post-test are more than the results of the initial test which fall into the category of good ability. Then the ability of students increases after passing the dubbing method (dubbing method).

The ability of students increased very high in the very good category (VG). From the data obtained in the pre-test results, 3 students who entered the VG category out of 44 students, only 3 people got a score of 80 , meaning that 41 other students got scores below eighty. But the changes were very far after getting treatment with the dubbing method (dubbing method), the students' abilities increased very high, namely in the pre-test results there were 3 students out of 44 participants who entered the VG category while in the post-test results there were 17 out of 44 students who entered the VG category. in the very good category. From three to seventeen people, the impact of change is very high through the application of the dubbing method in the classroom or in other words, an increase of almost forty percent of the number of students. So, the dubbing method works very effectively to improve students' ability to speak English. The students' speaking ability in the best category (Excellent category) was found by 1 student in the post-test results, while in the pre-test results there were no students who achieved a score of ninety and above. The value obtained by one student is the highest value based on the range, the value is 90-93. When compared with the results of the pre-test, there was not a single student who scored ninety.

\section{Discussion}

One of the primary skills in English that needs to be mastered is speaking skill. Speaking is the process of delivering messages or greetings to others to provide information (Liyana \& Kurniawan, 2019; Lorena \& Sadiku, 2015). Speaking is a productive and complicated skill to learn, involving many aspects, including pronunciation (Arfani \& Sulistia, 2019; Zuhriyah, 2017), as well as speaking as a skill that every individual needs to communicate through ideas, thoughts, feelings. A person is said to be a language speaker if he can speak that language. It can be concluded that speaking is one of the language skills that focuses on verbal interaction by producing, sending or receiving information accurately and fluently. Speakers must pay attention to vocabulary, grammar, and pronunciation. Because speaking is a productive activity in daily life and as the primary skill to have a conversation (Iftakhar, 2013; Liyana \& Kurniawan, 2019; Yusuf \& Mabagits, 2020). Teaching speaking aims to train students to interpret the contents of various spoken texts interactively in exciting activities (Lan \& Lam, 2020; Sharif Matthews \& 
López, 2019). In learning speaking skills, students have to know how to produce specific points of language such as grammar, pronunciation, and vocabulary, but they also have to understand when, why, and how to produce language. Furthermore, several elements of speaking will be used in this study, namely accuracy, pronunciation, fluency, and vocabulary (Nuraeni et al., 2019; Zijlstra et al., 2021).

The dubbing method will help students practice speaking skills. The dubbing method will help students practice speaking English (Liu \& Song, 2021; Sánchez-Mompeán, 2021). This method can help with learning media in the form of videos. The use of videos allows second/foreign language learners the opportunity to view and actively participate in lessons at their place (Fitriani et al., 2020; Yuniarni et al., 2020; Zulhaini et al., 2016). Video techniques help learners to gain information by placing them in real-life contexts. So videos can make things interesting for students and motivate students in the learning process (Mayang Ayu Sunami \& Aslam, 2021; Wisada et al., 2019). Therefore, short videos are tools or media in teaching speaking to make it easier for students and attract students' interest in the learning process. The duration of a short video or short video is about 3-6 minutes. Technological media such as video provides a new experience for students. Students get a new learning model that can allow them to dub or dub using English. Other research findings also state that learning videos can increase students' enthusiasm and motivation in learning (Novita et al., 2019; Pramana et al., 2016). It can be concluded that the dubbing method and learning videos can help students learn English.

\section{CONCLUSION}

There are differences in students' English speaking ability test results. The application of the dubbing method gave good and positive results in improving students' English-speaking skills. The application of the dubbing method in teaching speaking is very motivating and improves students' English skills so that students' English skills are proven to increase.

\section{REFERENCE}

Afif, M. (2019). Penerapan Metode Sorogan dalam Meningkatkan Baca Kitab di Pondok Pesantren Tarbiyatun Nasyi'in. KABILAH: Journal of Social Community. https://doi.org/10.35127/kbl.v4i2.3592.

Aini, Q., Rahardja, U., Tangkaw, M. R., Santoso, N. P. L., \& Khoirunisa, A. (2020). Embedding a Blockchain Technology Pattern Into the QR Code for an Authentication Certificate. Jurnal Online Informatika, 5(2). https://doi.org/10.15575/join.v5i2.583.

Alkubaidi, M. (2018). A Comparative Analysis of Writing Strategies and Performance in a Saudi University. Studies in Self-Access Learning Journal, 9, 425-443. https://doi.org/10.37237/090403.

Ammade, S., Mahmud, M., Jabu, B., \& Tahmir, S. (2020). TPACK model based instruction in teaching writing: An analysis on TPACK literacy. International Journal of Language Education, 4(1), 129140. https://doi.org/10.26858/ijole.v4i2.12441.

Arfani, S., \& Sulistia, A. (2019). Teaching Speaking Using A "Snake And Ladder" Board Game: A Teacher Story. Research and Innovation in Language Learning, 2(1). https://doi.org/10.33603/rill.v2i1.1642.

Asmi, A. R., Dhita Surbakti, A. N., \& C., H. (2018). E-Module Development Based Flip Book Maker For Character Building In Pancasila Coursework Sriwijaya University. Jurnal Pendidikan Ilmu Sosial, 27(1), 1-10. https://doi.org/10.17509/jpis.v27i1.9395.

Chamundeswari, S. (2013). Job satisfaction and performance of school teachers. International Journal of Academic Research in Business and Social Sciences, 3(5), 420-427. https://doi.org/10.11591/ijere.v8i4.20264.

Colasante, M., \& Douglas, K. (2016). Prepare-participate-connect: Active learning with video annotation. Australasian Journal of Educational Technology, 32(4), 68-91. https://doi.org/10.14742/ajet.2123.

Davidescu, A. A., Apostu, S.-A., Paul, A., \& Casuneanu, I. (2020). Work Flexibility, Job Satisfaction, and Job Performance among Romanian Employees-Implications for Sustainable Human Resource Management. Sustainability, 12(15), 6086. https://doi.org/10.3390/su12156086.

Djami, C. B. N., \& Kuswandono, P. (2020). Teachers' Strategies to Implement Higher-Order Thinking Skills in English Instruction. Metathesis: Journal of English Language, Literature, and Teaching, 4(1), 25. https://doi.org/10.31002/metathesis.v4i1.2048.

Dwi, N. M. L., Suwatra, I. I. W., \& Rasana, I. D. P. R. (2013). Pengaruh Model Pembelajaran Kooperatif Tipe Inside Outside Circle Terhadap Keterampilan Berbicara Bahasa Inggris Kelas IV SD Gugus X Kecamatan Buleleng. Mimbar PGSD Undiksha, 1(1). https://doi.org/10.23887/jjpgsd.v1i1.746. 
Febliza, A., \& Okatariani, 0. (2020). The Development of Online Learning Media by Using Moodle for General Chemistry Subject. Journal of Educational Science and Technology (EST), 6(1), 40. https://doi.org/10.26858/est.v6i1.12339.

Fitriani, A. A., Ulfa, S., \& Adi, E. P. (2020). Pengembangan Video Pembelajaran Animasi Sistem Pernapasan Manusia Sebagai Upaya Mendukung Kebijakan Belajar Di Rumah. JKTP Jurnal Kajian Teknologi Pendidikan, 3(3), 303-316. https://doi.org/10.17977/um038v3i32020p303.

Friantary, H., \& Martina, F. (2018). Evaluasi Implementasi Penilaian Hasil Belajar Berdasarkan Kurikulum 2013 oleh Guru Bahasa Inggris dan Bahasa Indonesia di MTS Ja-Alhaq Kota Bengkulu. Silampari Bisa: Jurnal Penelitian Pendidikan Bahasa Indonesia, Daerah, Dan Asing, 1(2), 76-95. https://doi.org/10.31540/silamparibisa.v1i2.202.

Halim, D. (2017). Pengembangan Video Pembelajaran IPA Pada Materi Pencemaran Dan Kerusakan Lingkungan. Jurnal Pendidikan Sains Indonesia, 5(2), 108-114. https: //doi.org/10.24815/jpsi.v5i2.9825.

Hatlevik, O. E., Throndsen, I., Loi, M., \& Gudmundsdottir, G. B. (2018). Students' ICT self-efficacy and computer and information literacy: Determinants and relationships. Computers and Education, 118,107-119. https://doi.org/10.1016/j.compedu.2017.11.011.

Hawkins, M. W. (2018). Self-directed learning as related to learning strategies, self-regulation, and autonomy in an English language program: A local application with global implications. Studies in Second Language Learning and Teaching, 8(2), 445-469. https://doi.org/10.14746/ssllt.2018.8.2.12.

Hill, C., Khoo, S., \& Hsieh, Y.-C. (2020). An investigation into the learning transfer of English for specific Academic Purposes (ESAP) writing skills of students in Singapore. Journal of English for Academic Purposes, 46. https://doi.org/10.1016/j.jeap.2020.100908.

Iftakhar, S. (2013). Teaching Speaking Through Public Speaking Course. Stamford Journal of English, 7. https://doi.org/10.3329/sje.v7i0.14473.

Ja'ashan, M. (2020). The Challenges and Prospects of Using E-learning among EFL Students in Bisha University. Arab World English Journal, 124-137. https://doi.org/10.24093/awej/vol11no1.11.

Kamelia, K. (2019). Using Video as Media of Teaching in English Language Classroom: Expressing Congratulation and Hopes. Utamax: Journal of Ultimate Research and Trends in Education, 1(1), 34-38. https://doi.org/10.31849/utamax.v1i1.2742

Khong, H. K., Hassan, N. H., \& Ramli, N. (2017). Motivation and gender differences in learning Spanish as a foreign language in a Malaysian Technical University. Malaysian Journal of Learning and Instruction. https://doi.org/10.32890/mjli2017.14.2.3.

Khotimah, K., Widiati, U., Mustofa, M., \& Faruq Ubaidillah, M. (2019). Autonomous English learning: Teachers' and students' perceptions. Indonesian Journal of Applied Linguistics, 9(2), 371-381. https://doi.org/10.17509/ijal.v9i2.20234.

Khusniyah, N. L., \& Hakim, L. (2019). Efektivitas Pembelajaran Berbasis Daring: Sebuah Bukti Pada Pembelajaran Bahasa Inggris. Jurnal Tatsqif, 17(1), 19-33. https: //doi.org/10.20414/jtq.v17i1.667.

Kusumah, R. G. T., Walid, A., Pitaloka, S., Dewi, P. S., \& Agustriana, N. (2020). Penerapan Metode Inquiry Untuk Meningkatkan Hasil Belajar Materi Penggolongan Hewan Di Kelas IV SD Seluma. Jurnal Pendidikan Matematika Dan IPA, 11(1), 142-153. https://doi.org/10.26418/jpmipa.v11i1.34708.

Lan, W., \& Lam, R. (2020). Exploring an efl teacher's beliefs and practices in teaching topical debates in mainland China. Iranian Journal of Language Teaching Research, 8(1), 25-44. https://doi.org/10.30466/ijltr.2020.120806.

Lestar, W. (2021). Pengembangan Modul Pembelajaran Bahasa Inggris Berbasis Andragogi Pada Program Studi Pendidikan Biologi di Universitas Muhammadiyah Palembang. Edunesia: Jurnal Ilmiah Pendidikan, 2(1), 171-177. https://doi.org/10.51276/edu.v2i1.114.

Liang, Y., Zheng, T., \& Wang, M. (2011). English audio-visual teaching mode and its teaching environment construction - Henan Institute of Science and Technology as the example. 2011 International Conference on Multimedia Technology, 3050-3053. https://doi.org/10.1109/ICMT.2011.6001924.

Liu, H., \& Song, X. (2021). Exploring “Flow" in young Chinese EFL learners' online English learning activities. System, 91. https://doi.org/10.1016/j.system.2020.102425.

Liyana, A., \& Kurniawan, M. (2019). Speaking Pyramid sebagai Media Pembelajaran Kosa Kata Bahasa Inggris Anak Usia 5-6 Tahun. Jurnal Obsesi: Jurnal Pendidikan Anak Usia Dini, 3(1). https://doi.org/10.31004/obsesi.v3i1.178.

Lorena, C., \& Sadiku, M. (2015). The Importance of Four Skills Reading, Speaking, Writing , Listening in a Lesson Hour. European Journal of Language and Literature Studies, 1(1), 29-31. 
https://doi.org/10.26417/ejls.v1i1.p29-31.

Lyashenko, M. S., \& Malinina, I. A. (2015). The Use of Learning Management System Projects for Teaching a Foreign Language in the University. Procedia - Social and Behavioral Sciences, 182, 81-88. https://doi.org/10.1016/j.sbspro.2015.04.741.

Mayang Ayu Sunami, \& Aslam. (2021). Pengaruh Penggunaan Media Pembelajaran Video Animasi Berbasis Zoom Meeting terhadap Minat dan Hasil Belajar IPA Siswa Sekolah Dasar. Jurnal Basicedu, 5(4), 19. https://doi.org/10.31004/basicedu.v5i4.1129.

Megawati, \& Utami. (2020). English Learning with Powtoon Animation Video. Journal of Education Technology, 4(2), 110. https://doi.org/10.23887/jet.v4i2.25096.

Misla, M., \& Mawardi, M. (2020). Efektifitas PBL dan Problem Solving Siswa SD Ditinjau dari Kemampuan Berpikir Kritis. Jurnal Ilmiah Sekolah Dasar, 4(1), 60. https://doi.org/10.23887/jisd.v4i1.24279.

Mustakim, M. (2020). Efektivitas Pembelajaran Daring Menggunakan Media Online Selama Pandemi Covid-19 Pada Mata Pelajaran Matematika. Al Asma: Journal of Islamic Education, 2(1), 1-12. https://doi.org/10.24252/asma.v2i1.13646.

Noge, M. D. (2019). Penerapan Model Pembelajaran Bilingual Preview-Review Berbasis E-Flashcard Untuk Meningkatkan Aktivitas Dan Prestasi Belajar Bahasa Inggris Siswa Smp. Journal of Education Technology, 2(1), 13. https://doi.org/10.23887/jet.v2i1.13801.

Novita, Sukmanasa, \& Pratama. (2019). Penggunaan Media Pembelajaran Video Terhadap Hasil Belajar Siswa SD. Indonesian Journal of Primary Education, 3(2), 64-72. https://doi.org/10.17509/ijpe.v3i2.22103.

Noviyanto, T. S. H., Juanengsih, N., \& Rosyidatun, E. S. (2015). Penggunaan Media Video Animasi Sistem Pernapasan Manusia Untuk Meningkatkan Hasil Belajar Biologi. Edusains, 7(1), 57-63. https://doi.org/10.15408/es.v7i1.1215.

Nuraeni, S., Maesaroh, A., \& Sumitra, A. (2019). Optimalisasi Keterampilan Berbicara Untuk Meningkatkan Keyakinan Diri Anak Usia Dini Di Tk Baiturrahman Kabupaten Bandung. CERIA (Cerdas Energik Responsif Inovatif Adaptif), 2(4). https://doi.org/10.22460/ceria.v2i4.p166-172.

Nurrohmah, F., Putra, F. G., \& Farida, F. (2018). Development of Sparkol Video Scribe Assisted Learning Media. Formatif: Jurnal Ilmiah Pendidikan MIPA, 8(3), 233-250. https://doi.org/10.30998/formatif.v8i3.2613.

Pramana, I. P. A., Tegeh, I. M., \& Agung, A. A. G. (2016). Pengembangan Video Pembelajaran IPA Kelas VI di SD N 2 Banjar Bali Tahun 2015/2016. E-Journal Edutech Universitas Pendidikan Ganesha Jurusan Teknologi Pendidikan, 5(2). https://doi.org/10.23887/jeu.v4i2.7631.

Pratiwi, K. Y., Rasana, I. D. P. R., \& Pudjawan, K. (2018). Pengaruh Model Pembelajaran Teams Games Tournament ( Tgt ) Terhadap Penguasaan Kosakata Bahasa Inggris Siswa Kelas Iv Sd Gugus Iv Kecamatan Tabanan. JJPGSD, 1(1). https://doi.org/10.23887/jjpgsd.v1i1.790.

Putri, A., Kuswandi, D., \& Susilaningsih, S. (2020). Pengembangan Video Edukasi Kartun Animasi Materi Siklus Air untuk Memfasilitasi Siswa Sekolah Dasar. JKTP: Jurnal Kajian Teknologi Pendidikan, 3(4), 377-387. https://doi.org/10.17977/um038v3i42020p377.

Ratminingsih, N. M. (2018). Implementasi Board Games Dan Pengaruhnya Terhadap Hasil Belajar Bahasa Inggris. Jurnal Ilmu Pendidikan, 24(1), 19. https://doi.org/10.17977/um048v24i1p19-28.

Risnawati, A., \& Nuraeni, L. (2019). Meningkatkan Kemampuan Berbahasa Sunda Anak Usia Dini Melalui Kegiatan Rebo Nyunda Di Pendidikan Anak Usia Dini. CERIA (Cerdas Energik Responsif Inovatif Adaptif), 2(5). https://doi.org/10.22460/ceria.v2i5.p243-250.

Sahin, D., \& Yilmaz, R. M. (2020). The effect of Augmented Reality Technology on middle school students' achievements and attitudes towards science education. Computers \& Education, 144. https://doi.org/10.1016/j.compedu.2019.103710.

Sánchez-Mompeán, S. (2021). Netflix likes it dubbed: Taking on the challenge of dubbing into English. Language \& Communication, 80. https://doi.org/10.1016/j.langcom.2021.07.001.

Sartika, S. H., Dahlan, D., \& Waspada, I. (2018). Kompetensi Guru Dan Motivasi Belajar Siswa Terhadap Hasil Belajar Melalui Kebiasaan Belajar Siswa. Manajerial: Jurnal Manajemen Dan Sistem Informasi, 17(1), 39-51. https://doi.org/10.17509/manajerial.v17i1.9760.

Sert, N., \& Boynueğri, E. (2017). Digital technology use by the students and english teachers and selfdirected language learning. World Journal on Educational Technology: Current Issues, 9(1), 24. https://doi.org/10.18844/wjet.v9i1.993.

Sharif Matthews, J., \& López, F. (2019). Speaking their language: The role of cultural content integration and heritage language for academic achievement among Latino children. Contemporary Educational Psychology, 57, 72-86. https://doi.org/10.1016/j.cedpsych.2018.01.005.

Shaukat, S., Vishnumolakala, V. R., \& Al Bustami, G. (2019). The impact of teachers' characteristics on their self-efficacy and job satisfaction: a perspective from teachers engaging students with disabilities. 
Journal of Research in Special Educational Needs, 19(1), 68-76. https://doi.org/10.1111/14713802.12425.

Sirivedin, P., Soopunyo, W., Srisuantang, S., \& Wongsothorn, A. (2018). Effects of Facebook usage on English learning behavior of Thai English teachers. Kasetsart Journal of Social Sciences, 39(2). https://doi.org/10.1016/j.kjss.2018.03.007.

Sudiarta, \& Sadra. (2016). Pengaruh model blended learning berbantuan video animasi terhadap kemampuan pemecahan masalah dan pemahaman konsep siswa. Jurnal Pendidikan Dan Pengajaran, 49(2), 48-58. https://doi.org/10.23887/jppundiksha.v49i2.9009.

Suhandra, I. R. (2018). Pemanfaatan media gambar berseri untuk memperkaya kemampuan menulis naratif bahasa inggris siswa kelas IX MTS NW Nurul Wathon Pengembur Lombok Tengah. TRANSFORMASI: Jurnal Pengabdian Masyarakat, 14(1). https://doi.org/10.20414/transformasi.v14i1.576.

Surjono, J. (2016). Pengembangan Multimedia Pembelajaran Bahasa Inggris Untuk Pembelajaran Teks Recount Di Mtsn II Yogyakarta. Jurnal Inovasi Teknologi Pendidikan, 3(1), 25-39. https://doi.org/10.21831/tp.v3i1.8287.

Suryansah, T., \& Suwarjo, S. (2016). Pengembangan Video Pembelajaran Untuk Meningkatkan Motivasi Dan Hasil Belajar Kognitif Siswa Kelas Iv Sd. Jurnal Prima Edukasia, 4(2), 209. https://doi.org/10.21831/jpe.v4i2.8393.

Syawaluddin, \& Iswari, M. (2015). Penerapan Model Pembelajaran Saintifik untuk Meningkatkan Aktivitas dan Hasil Belajar enerapan Model Pembelajaran Saintifik untukMeningkatkan Aktivitas dan Hasil Belajar Bahasa Inggris Topik Prosedur Teks Kelas IX SMP. Jurnal Konseling Dan Pendidikan, 2(1), 55-61. https://doi.org/10.31004/obsesi.v3i1.136.

Szanto, B. (2020). Reading and Writing Comprehension in the Mother Tongue in the Romanian National Assessment - Objectives, Tests, Results. Technium Social Science Journal, 9. https://doi.org/10.47577/tssj.v9i1.933.

Teng, (Mark) Feng. (2019). The effects of video caption types and advance organizers on incidental L2 $\begin{array}{lllll}\text { collocation learning. } & \text { Computers Education, } & 142 .\end{array}$ https://doi.org/10.1016/j.compedu.2019.103655.

Van Alten, D. C. D., Phielix, C., Janssen, J., \& Kester, L. (2020). Self-regulated learning support in flipped learning videos enhances learning outcomes. Computers and Education, 158(August), 104000. https://doi.org/10.1016/j.compedu.2020.104000.

Virgiana, A., \& Wasitohadi. (2016). Efektivitas Model Problem Based Learning Berbantuan Media Audio Visual Ditinjau Dari Hasil Belajar IPA Siswa Kelas 5 SDN 1 Gadu Sambong - Blora Semester 2 Tahun 2014/2015. Scholaria: Jurnal Pendidikan Dan Kebudayaan, 6(2), 100-118. https://doi.org/10.24246/j.scholaria.2016.v6.i2.p100-118.

Wichadee, S. (2011). Developing The Self-Directed Learning Instructional Model To Enhance English Reading Ability And Self-Directed Learning Of Undergraduate Students. Journal of College Teaching \& Learning (TLC), 8(12), 43. https://doi.org/10.19030/tlc.v8i12.6620.

Wisada, P. D., Sudarma, I. K., \& Yuda S, A. I. W. I. (2019). Pengembangan Media Video Pembelajaran Berorientasi Pendidikan Karakter. Journal of Education Technology, 3(3), 140. https://doi.org/10.23887/jet.v3i3.21735.

Yuniarni, D., Sari, R. P., \& Atiq, A. (2020). Pengembangan Multimedia Interaktif Video Senam Animasi Berbasis Budaya Khas Kalimantan Barat. Jurnal Obsesi : Jurnal Pendidikan Anak Usia Dini, 4(1), 290. https://doi.org/10.31004/obsesi.v4i1.331.

Yusuf, K., \& Mabagits, S. (2020). Does Activeness in Organization Improve English Speaking Skill? University Students' Perspective. Leksika Jurnal Bahasa, Sastra Dan Pengajarannya, 14(2). https://doi.org/10.31838/jcr.07.12.41.

Zabrodina, I. K., Bogdanova, A. G., Bogdanova, V., Lilenko, I. Y., \& Richter, S. O. (2015). Experimental Learning of Foreign Language with the Socio-cultural Skills Development Method by Means of Modern Internet Technologies. Procedia - Social and Behavioral Sciences, 215(June), 141-146. https://doi.org/10.1016/j.sbspro.2015.11.602.

Zijlstra, H., van Bergen, E., Regtvoort, A., de Jong, P. F., \& van der Leij, A. (2021). Prevention of reading difficulties in children with and without familial risk: Short- and long-term effects of an early intervention. Journal of Educational Psychology, 113(2). https://doi.org/10.1037/edu0000489.

Zuhriyah, M. (2017). Storytelling to Improve Students' Speaking Skill. English Education: Jurnal Tadris Bahasa Inggris, 10(1), 119-134. https://doi.org/10.24042/ee-jtbi.v10i1.879.

Zulhaini, Halim, A., \& Mursal. (2016). Pengembangan Modul Fisika Kontekstual Hukum Newton Untuk Meningkatkan Pemahaman Konsep Fisika Siswa Di Man Model Banda Aceh. Jurnal Pendidikan Sains Indonesia, 4(1), 121346. https://doi.org/10.24815/jpsi.v4i1.6596. 